\title{
Effectiveness of Structured Teaching Programme on Knowledge regarding Health Hazards of Plastic use among Students -A Quasi Experimental Study
}

\section{Kaur S*, Jeganathan J, Kaur M}

Akal College of Nursing, Eternal University, India

*Corresponding author: Simarjeet Kaur, Akal College of Nursing, Eternal University, VPO Baru Sahib, Teh Pachhad, Distt, India, Tel: 9816421609; Email: simarjeet3011@gmail.com

\section{Research Article}

Volume 3 Issue 2

Received Date: February 15, 2019

Published Date: March 05, 2019

\section{Abstract}

Plastic is an integral part of human life. Plastic waste has several impacts on ecosystem and human life. The present study was selected to create awareness with the help of structured teaching programme among students of Private Institutions of District Sirmour, Himachal Pradesh.

Methodology: A Quasi-experimental research design was selected to conduct the study among 30 Female students selected through simple random sampling technique studying in selected private institutions of district Sirmour, Himachal Pradesh. Structured teaching programme was given to experimental group and data was collected with selfstructured questionnaire. Data analysis was done with SPSS.

Results: The study results revealed that in Experimental group, during pre-test 60\% of them had poor knowledge and $40 \%$ had average knowledge and none of them had good knowledge regarding health hazards of plastic use. After intervention of structured teaching program, during post-test, $40 \%$ of them had good knowledge and $60 \%$ of them had average knowledge regarding health hazards of plastic use among students. The difference between pre-test and posttest score of knowledge in experimental group was statistically significant at 0.01 level.

There was significant association of age with knowledge regarding health hazards of plastic use among students at $\mathrm{p}<0.01$ level of significance.

Conclusion \& Recommendation: The study emphasis for effective implementation of legislation to minimize the plastic use in the community. There is need for parent's awareness and In-service education programme for teachers about hazards of plastic use so that they can create more awareness among students regarding hazards of plastic use.

Keywords: Structured Teaching Programme; Health hazards of plastic use; Students 


\section{Nursing \& Healthcare International Journal}

\section{Introduction}

Millions of tonnes of plastic enter the seas each year, choking whales and other creatures [1]. Plastic waste has several impacts on health of ecosystems and humans. Human health effects includes decreased immune function, cataract, kidney and liver damage, lung function abnormalities and trigger development of obesity and diabetics, irritation in the eyes, nose and throat [2].

India, which has $7,500 \mathrm{~km}$ of coastline, also announced a national marine litter action campaign and a programme to measure how much plastic enters India's coastal waters [3]. Much of the growth in plastic production is driven by single use or disposable applications. Nearly $50 \%$ of plastics used are single use products such as bottles, plastic bags, packaging, straws, stirrers, and forks. Around the world, 1 million plastic drinking bottles are purchased every minute. Every year we use up to 5 trillion disposable plastic uses. Every year, nearly 13 million tonnes of plastic waste are added to oceans [4].

The central government has recently passed a ruling under the provisions of the Environment Protection Act 1986, restricting the sale of some products in plastic carry bags. Recently, the government notified the Plastic Waste (Management and Handling) Rules, 2011, to replace the earlier Recycled Plastics Manufacture and Usage Rules, 2003 , towards better management of plastic waste [5].

In 2018, World Environmental Day (5 June, 2018) has come up theme of 'Beat plastic pollution- The world is coming together to combat single use plastic pollution'. India is emerging as a leader, given its one of the highest recycling rates in the world [6]. So, there is need to create awareness among people of India regarding adequate disposal and recycling of plastic waste which leads the intervention of study.

\section{Objectives}

- To assess the pre-test score of knowledge regarding hazards of plastic use in experimental group of students.

- To prepare and provide a Structured Teaching Programme on health hazards of plastic use to experimental group of students.

- To assess the post-test score of knowledge regarding hazards of plastic use in experimental group of students
- To compare pre and post test score of knowledge regarding hazards of plastic use in experimental group of students.

- To find out the association of knowledge regarding hazards of plastic use among students with selected demographic variables.

\section{Research Hypothesis}

H1: The mean post-test knowledge scores of students exposed to Structured Teaching Programme will be significantly higher than mean pre-test knowledge scores as evident from structured knowledge questionnaire, at 0.05 level of significance.

\section{Materials and Methods}

Quantitative research approach and Quasiexperimental design was used to assess the effectiveness of structured teaching programme on knowledge regarding health hazards of plastic use among 30 students who were selected through simple random technique studying in selected Private Educational Institution of district Sirmour, Himachal Pradesh. Ethical committee permission was obtained before conducting the study. Consent was taken prior to data collection. Confidentiality of subjects and data was ensured. Data was collected using Social-demographic data sheet developed by the researcher and knowledge questionnaire on health hazards of plastic use were used to assess the level of knowledge. Structured teaching programme was implemented after pre-test. Content validity was obtained from experts of Community Health Nursing and Public Health department. Data was analysed by using SPSS. The descriptive and inferential statistics such as percentage, SD,T-test and Chi Square was used to identify the significant relationship of knowledge of adolescent girls regarding health hazards of plastic use.

\section{Results and Discussion}

\section{Section I: Description of Socio-Demographic Characteristics of the Subjects}

With respect to the age, majority (46.7\%) of the subjects were between the ages of 19-20 years old. Majority (90\%) of respondents belongs to Sikh religion. All of them were female students. Most of them (83.3\%) were from rural area. Majority (53.3\%) of respondents were from joint families. Majority (33.4\%) respondent's parental education was middle school. $63.3 \%$ of respondents has family income $>15000$ (Table 1). 


\begin{tabular}{|c|c|c|c|}
\hline S.No. & Demographic Variables & $\mathbf{N}$ & $\%$ \\
\hline \multirow{5}{*}{1} & \multicolumn{3}{|c|}{ Age (in yrs) } \\
\hline & a) $15-16$ & 3 & 10 \\
\hline & b) $17-18$ & 8 & 26.6 \\
\hline & c) $19-20$ & 14 & 46.7 \\
\hline & d) 21-22 & 5 & 16.7 \\
\hline \multirow{3}{*}{2} & \multicolumn{3}{|l|}{ Religion } \\
\hline & a) Hindu & 3 & 10 \\
\hline & b) Sikh & 27 & 90 \\
\hline \multirow{3}{*}{3} & \multicolumn{3}{|l|}{ Gender } \\
\hline & a) Female & 30 & 100 \\
\hline & b) Male & 0 & 0 \\
\hline \multirow{4}{*}{4} & \multicolumn{3}{|c|}{ Residence } \\
\hline & a) Urban & 3 & 30 \\
\hline & b) Semi Urban & 2 & 6.67 \\
\hline & c)Rural & 25 & 83.3 \\
\hline \multirow{3}{*}{5} & \multicolumn{3}{|c|}{ Type of family } \\
\hline & a) Nuclear & 14 & 46.7 \\
\hline & b)Joint & 16 & 53.3 \\
\hline \multirow{5}{*}{6} & \multicolumn{3}{|c|}{ Parental Education } \\
\hline & a) Illiterate & 4 & 13.3 \\
\hline & b) Primary & 7 & 23.3 \\
\hline & c)Middle & 10 & 33.4 \\
\hline & d)Senior secondary or above & 9 & 30 \\
\hline \multirow{5}{*}{7} & \multicolumn{3}{|c|}{ Family Income } \\
\hline & a. $\leq 5000$ & 6 & 20 \\
\hline & b. $5001-10000$ & 3 & 10 \\
\hline & c. $10000-15000$ & 2 & 6.67 \\
\hline & d. $>15000$ & 19 & 63.3 \\
\hline
\end{tabular}

Table 1: Frequency and Percentage distribution of socio-demographic variables of the subjects $N=30$.

\section{Section II: Plastic Use among the Subjects}

\begin{tabular}{|c|c|c|c|c|}
\hline S. No. & Items & Category & $\mathbf{N}$ & $\%$ \\
\hline \multirow{2}{*}{1} & \multirow{2}{*}{ Do you use plastic items? } & Yes & 20 & 66.7 \\
\hline & & No & 10 & 33.3 \\
\hline \multirow{3}{*}{2} & \multirow{3}{*}{$\begin{array}{l}\text { When you go for shopping in a market, which of } \\
\text { these would you prefer? }\end{array}$} & Free plastic carrier bag & 6 & 20 \\
\hline & & Free plastic bag which is degradable & 10 & 33.3 \\
\hline & & Bag, even if I have to pay for it & 14 & 46.7 \\
\hline \multirow{4}{*}{3} & \multirow{4}{*}{ Practices of plastic bag waste disposal } & Dumping in open places & 5 & 16.7 \\
\hline & & Burning & 13 & 43.3 \\
\hline & & Burying & 4 & 13.3 \\
\hline & & Others & 8 & 26.7 \\
\hline \multirow{3}{*}{4} & \multirow{3}{*}{$\begin{array}{l}\text { After you finish using the plastic what do you do with } \\
\text { it? }\end{array}$} & Throw it into the dustbin & 15 & 50 \\
\hline & & Recycle & 8 & 26.6 \\
\hline & & Reuse & 7 & 23.4 \\
\hline \multirow{4}{*}{5} & \multirow{4}{*}{$\begin{array}{l}\text { How many times do you re-use your plastic carrier } \\
\text { bag? }\end{array}$} & I don't re-use plastic bags ever & 12 & 40 \\
\hline & & I re-use it only once & 6 & 20 \\
\hline & & I re-use it 2-5 times & 4 & 13.4 \\
\hline & & I re-use it more than 5 times & 8 & 26.7 \\
\hline
\end{tabular}

Kaur S, et al. Effectiveness of Structured Teaching Programme on 


\section{Nursing \& Healthcare International Journal}

\begin{tabular}{|c|c|c|c|c|}
\hline \multirow{2}{*}{6} & Does Plastics affect our environment? & Yes & 26 & 86.7 \\
\cline { 3 - 4 } & & No & 4 & 13.3 \\
\hline \multirow{2}{*}{7} & Are you aware of the plastic is causing health & Yes & 21 & 70 \\
\cline { 3 - 4 } & hazards? & No & 9 & 30 \\
\hline \multirow{2}{*}{8} & \multirow{2}{*}{ Is your area badly affected by plastics? } & It's a total rubbish & 4 & 13.3 \\
\cline { 3 - 5 } & & Its average & 17 & 56.7 \\
\cline { 3 - 5 } & & Pretty good & 9 & 30 \\
\hline \multirow{2}{*}{9} & Do you aware about any laws regulating the plastic & Yes & 17 & 56.7 \\
\cline { 3 - 5 } & use in our country? & No & 43.3 \\
\hline \multirow{2}{*}{10} & \multirow{2}{*}{ Have you attended any program on plastic use? } & Yes & 23.3 \\
\cline { 3 - 5 } & & No & 76.7 \\
\hline
\end{tabular}

Table 2: Frequency and Percentage distribution of item wise response of the subjects regarding plastic use $(\mathrm{N}=30)$.

Regarding the use of plastic items, Majority (66.7\%) of the subjects were using plastic items on daily basis similar finding was reported in a study that majority $(83.3 \%)$ of the respondents are having high level on plastic usage [7]. While shopping $46.7 \%$ of the subjects prefers to use plastic bag even they have to pay for it.

Regarding the practices of plastic bags waste disposal, $43.3 \%$ of them dispose the plastic by burning in open places; a study finding revealed that $70 \%$ of participants burn the plastics including bags and bottles [8]. In this study $50 \%$ of them throw it into the dustbin (Table 2).

In the current study, $40 \%$ of the subjects don't reuse the plastic bags and $26.7 \%$ of them uses the plastic bags more than five times. Similar study finding revealed that $20 \%$ participants reusing plastic bags for shopping after initial usage [9].

Majority $86.7 \%$ of the subjects conveyed that plastic use affects the environment, and $70 \%$ of them were aware that plastic use can affect their health. Majority (56.7\%) of the subjects reported that their surrounding areas were found to average affected by plastic.

This study reveals that $56.7 \%$ of the subjects were having the awareness about laws regulating the plastic use, a study finding reported that among the participants $85.2 \%$ were aware of the legislation banning the use of plastic bags and out of which $77.9 \%$ were in its favour. Majority (76.7\%) of them have not attended any awareness program on plastic use.

Section III: Frequency and Percentage Distribution of Pre-Test and Post-Test Score of Experimental Group Regarding Knowledge on Health Hazards of Plastic Use among the Subjects

In Experimental group, during pre-test $60 \%$ of them had poor knowledge and $40 \%$ had average knowledge and none of them had good knowledge regarding health hazards of plastic use. After intervention of structured teaching program, during post-test $40 \%$ of them had good knowledge and $60 \%$ of them had average knowledge regarding health hazards of plastic use among students (Table 3).

\begin{tabular}{|c|c|c|c|c|}
\hline \multirow{2}{*}{ Experimental Group (Level of Knowledge) } & \multicolumn{2}{|c|}{ Pre test } & \multicolumn{2}{c|}{ Post test } \\
\cline { 2 - 5 } & $\mathbf{N}$ & $\mathbf{\%}$ & $\mathbf{N}$ & $\mathbf{\%}$ \\
\hline Good(21-30) & 0 & 0 & 12 & 40 \\
\hline Average(11-20) & 12 & 40 & 18 & 60 \\
\hline Poor(1-10) & 18 & 60 & 0 & 0 \\
\hline
\end{tabular}

Table3: Frequency \& Percentage distribution of Pre-test \& Post-test Score of knowledge on health hazards of plastic use among the subjects (N-30).

Minimum Score: 0 Maximum Score: 30

Section IV: Comparison of Pre-Test and Post Score of Experimental Group Regarding Knowledge on Health Hazards of Plastic Use among the Subjects
Table 4 revealed that in experimental group, mean pretest knowledge score was 7.9 and mean post-test knowledge score was 19.2. The difference between mean pre-test and post-test knowledge score of experimental 


\section{Nursing \& Healthcare International Journal}

group was statistical significant at 0.01 level of significance.

\begin{tabular}{|c|c|c|c|}
\hline \multirow{2}{*}{ GROUP } & \multicolumn{2}{|c|}{ Knowledge Score } & \multirow{2}{*}{ Paired t-test } \\
\hline & Pre-test Mean \pm SD & Post -test Mean \pm SD & \\
\hline Experimental Group $(\mathrm{n}=30)$ & $7.9 \pm 1.68$ & $19.2 \pm 4.27$ & t value $-12.12 \mathrm{df}=29 \mathrm{p}=0.000^{*}$ \\
\hline
\end{tabular}

Table 4: Comparison of Pre-test \& Post-test knowledge score of subjects regarding health hazards of plastic use among the subjects $(\mathrm{N}-30)$.

Minimum Score $=0 *$ Significant at $\mathrm{p}<0.01$.

Maximum Score $=30$

Hence, research hypothesis (H1) was accepted. So, it was concluded that Structured Teaching Programme had impact on knowledge of students regarding health hazards of plastic use.

Similar findings were reported in a study conducted by Punitha, et al. (2016), the participants $53.3 \%$ had moderately adequate knowledge and $33.3 \%$ had inadequate knowledge regarding hazards of plastic use [9]. There was significant association of age with knowledge regarding health hazards of plastic use among students at significant level of 0.01 level of significance using chi square test.

\section{Recommendations}

- Parents should guide their children to minimize the plastic use. Help them to replace the plastic bags, paper bags or cloth.

- Conduct in-service education programmes for teachers about hazards of plastic use so that they can create more awareness among students regarding hazards of plastic use.

\section{Conclusion}

The present study has concluded that Structured Teaching Programme is effective in increasing knowledge of students regarding use of plastic and there is need of effective implementation of legislation to minimize the plastic use in the community.

\section{References}

1. Toxics Link (2014) Plastics and the Environment Assessing the Impact of the Complete Ban on Plastic Carry Bag, New Delhi.
2. Elias Hans G (2003) An Introduction to Plastics. $4^{\text {th }}($ edn), Weinheim: Wiley \& Weinheim Publishers, pp: 121-125.

3. Archana Jyoti (2018) India's 7,500-km coastline aims to be plastic free, New Delhi.

4. Plastic Waste (2018) European Commission.

5. Vigneshwaran R, Arun kumar B (2014) Knowledge Attitude and Practice on Plastic Usage Among the Residents of Tiruchirappalli Municipal Corporation, Tamil Nadu -A Descriptive Study. IOSR Journal of Humanities And Social Science (IOSR-JHSS) 12(8): 3339.

6. Huntley S (2005) Public Health Implication of Household Solid Waste Management. The Internet Journal of Public Health 37(3): 119-137

7. Chaggu EJ, Kaseva ME (2010) Effects of open burning of Domestic wastes. Dares salaam medical students' journal 35(1): 170-171.

8. Joseph N, Kumar A, Majgi SM, Kumar GS, Prahalad RB (2016) Usage of Plastic Bags and Health Hazards: A Study to Assess Awareness Level and Perception about Legislation among a Small Population of Mangalore. City J Clin Diagn Res 10(4).

9. Punitha K, Hemavathy V (2016) A study to assess the effectiveness of structured teaching programme regarding hazards of plastic use among school going children in hilton matriculation higher secondary school, Chrompet, Chennai-44.International Journal of Nursing and Patient Safety \& Care 1(1): 43-48. 